\title{
IN VIVO ANTIDIABETIC SCREENING OF KABAU (ARCHIDENDRON BUBALINUM (JACK) I. C NIELSEN) SEEDS
}

\section{HESTI RIASARI ${ }^{12^{*}}$, NOVI IRWAN FAUZI ${ }^{2}$, KUSNANDAR ANGGADIREDJA ${ }^{1}$, RIKA HARTATI ${ }^{1}$, SUKRASNO ${ }^{1}$}

1Department of Pharmaceutical Biology, School of Pharmacy, Institut Teknologi Bandung, Jl Ganesha 10, Bandung 40132, West Java, Indonesia, 2Indonesian School of Pharmacy, Jl Soekarno Hatta 354, Bandung 40266 West Java, Indonesia

*Email: hestiriasari@stfi.ac.id

Received: 20 Aug 2021, Revised and Accepted: 05 Oct 2021

ABSTRACT

Objective: Study described the screening potential antidiabetic activity of kabau seed extract and fraction.

Methods: The powdered crude drugs weighing 1349.32 grams were extracted with a solvent with solvents with escalating polarity by using soxhletation. The solvents used were n-hexane, ethyl acetate, and $96 \%$ ethanol. Screening activity using three variations on doses on the three extracts using the glucose test tolerance method, then the alloxan induction and high-fat feed induction testing methods using selected doses, decreasing blood glucose levels using the GOD PAP enzyme and decreasing MDA levels and increased levels of the enzyme SOD. Extracts that have potential antidiabetic activity are fractionated using liquid-solid fractionation; then the fraction is screened for antidiabetic activity using the glucose test tolerance method.

Results: Screening for antidiabetic activity on the three extracts using the glucose test tolerance method showed that the ethanol extract at a dose of $250 \mathrm{mg} / \mathrm{kg} \mathrm{BW}$. The three extracts were then screened for the next mechanism using the alloxan induction method and high-fat feed induction, the decrease in blood sugar levels by the GOD-PAP method showed a good decrease in the ethanol extract by $202.94 \pm 2$ mg/dl, the three extracts showed good less significant, in the SOD enzyme method, the ethanol extract gave a good value such as the positive control value. Testing on fraction can decrease in blood sugar; the results showed that the ethanol extract and methanol fraction gave a small AUC $0-150$ (32695,3 and $33167,71)$, where the value was close to the result of the glibenclamide 30238,48 .

Conclusion: The antidiabetic activity of the extract showed that the ethanol extract was better with the glucose test tolerance method, with alloxan induction animal models and high-fat feed induction. In the methanol fraction derived from $96 \%$ ethanol extract, it provides a good reduction in blood sugar levels in the screening method with a glucose test tolerance

Keywords: Antidiabetic, Archidendron bubalinum, MDA, SOD enzyme, Ethanol extract, Fraction active

(C) 2021 The Authors.Published by Innovare Academic Sciences Pvt Ltd. Thisis an open access article under theCCBYlicense (https://creativecommons.org/licenses/by/4.0/) DOI: https://dx.doi.org/10.22159/ijap.2021.v13s4.43865 Journal homepage: https://innovareacademics.in/journals/index.php/ijap

\section{INTRODUCTION}

Diabetes mellitus (DM) is a metabolic disorder [1] that can occur due to damage to the pancreas, causing a decrease in insulin production, insulin action, or both causing glucose metabolic disorders. High blood sugar produces symptoms, including polyuria, polydipsia. Oxidative stress arises when the generation of reactive oxygen species (ROS) exceeds the available antioxidant defenses [2]. ROS are chemically reactive molecules containing oxygen e. . $\mathrm{H}_{2} \mathrm{O}_{2}, \mathrm{HOCl}$, and free radicals such as superoxide anions, hydroxyl radicals. Antioxidants are molecules involved in scavenging free radicals; this defense mechanism involves enzymatic and non-enzymatic strategies. Enzymes include superoxide dismutase (SOD), catalase, glutathione peroxidase, and enzymes including small molecules uric acid, vitamins E, C, and A [3]. Numerous studies have shown that oxidative stress, which is mediated mainly by hyperglycemia-induced by the generation of free radicals, contributes to the development of diabetes and its complications [4]. Diabetes neuropathy, which is one of the most frequent long-term complications of diabetes mellitus, is often accompanied by a lower quality of life. This complication occurs in about a quarter of diabetic patients. Painful diabetes neuropathy is combined with symptoms and signs such as spontaneous burning, tingling, or lancing, allodynia, and hyperalgesia [5].

The high number of people with diabetes mellitus in Indonesia has prompted efforts to develop antidiabetic drugs, one of which comes from plants used as traditional medicine, namely kabau (Archidendron bubalinum (Jack) I. C Nielsen) is one of the plants used for such a purpose [6]. The Fabaceae are members of the Fabales with pod-type fruit peculiarities $[7,8]$. This tribe is widely distributed throughout the world and consists of 18,000 species covered in 650 genera [9]. Subfamily from Fabaceae, namely Mimosoideae, has been empirically used to treat diabetes and among the plants belonging to mimosoideae used for this purpose is petai cina. The leaves of contain mimosin leukanin, leukanol, and protein, the leaves of this plant also contain alkaloids, saponins, flavonoids, tannins, proteins, fats, calcium, phosphorus, iron, and a number of vitamins (A, B1, and C) [10].

Earlier phytochemical study of kabau plants demonstrated that the extract of the seed coat contained various compounds that have bioactivity potential. All extracts showed antioxidant activity in various levels. The $\mathrm{IC}_{50}$ values were $273.57,324.913$, and 735 ppm, respectively, for ethyl acetate, methanol and n-hexane extract [11] Meanwhile, our previous result [12] states that the extraction method and the difference in the place of growth affect the phenolic content and antioxidant activity. The use of maceration on the seeds and bark of kabau is better than the soxhlet method; the highest antioxidant activity and total phenol levels are found in the seeds and bark of kabau originating from South Sumatra with the maceration method.

\section{MATERIALS AND METHODS}

\section{Plant materials}

Kabau seeds (Archidendron bubalinum (Jack) Nielsen), Fabaceae were collected in January 2018 from Bumi Baru village, Blambangan Umpu District, Waykanan Regency, Lampung, Sumatra Island, Indonesia. The plant was determined at the Indonesian Institute of Sciences, Biological Research Center, LIPI Bogor, number: 408/IPH. I.01/If.07/II/2018 on February 13, 2018. The seeds were separated from the black seed coat, then washed with running water to remove dirt, cut into small pieces to speed up the drying process, dried at room temperature in an air oven then made into powder.

\section{Animals}

The experimental animals used in this study were Wistar strain male white rats with body weights of 150-250 grams obtained from PT. 
Biofarma, use and care for the experimental animals were approved by the Ethic Committee of Padjadjaran University (Approval No 114/UN6. KEP/EC/2019).

\section{Extract preparation}

The powdered crude drugs weighing 1349.32 grams were extracted with a solvent with solvents with escalating polarity by using soxhletation. The solvents used were n-hexane, ethyl acetate, and $96 \%$ ethanol; each was used in a quantity of 4.5 liters. The extraction was carried out at a range of temperature of $40-50{ }^{\circ} \mathrm{C}$. The extract is concentrated using a rotary evaporator at $50{ }^{\circ} \mathrm{C}$ followed by drying with aeration. The dregs are removed and dried by aerating. The dried dregs were then extracted with ethyl acetate and 4.5 liters of $96 \%$ ethanol (the extraction method was the same as with n-hexane as solvent). Thes concentrated extracts were weighed to determine. The yield extracted values and was stored at $4{ }^{\circ} \mathrm{C}$ for further investigation.

\section{Glucose tolerance test}

The rats were divided into six groups as follows group I (normal group); group II (negative control, given $0.5 \% \mathrm{CMC} \mathrm{Na);} \mathrm{group} \mathrm{III}$ (positive control, given $0.45 \mathrm{mg} / \mathrm{kg}$ glibenclamide), group IV (given $n$-hexane kabau seed extract at 250,500 , and $750 \mathrm{mg}$; group $\mathrm{V}$ (given kabau seed ethyl acetate extract at 250,500 , and $750 \mathrm{ml}$; group VI (given kabau seed ethanol extract at 250, 500, and $750 \mathrm{mg}$. fifteen minutes after oral administration of vehicle or test extract, each rat was given glucose at doses of $6.3 \mathrm{~g} / \mathrm{kg}$ orally. Glucose levels were measured before the administration of vehicle Ior test extract and at $30,60,90,120$, and $150 \min [14]$.

\section{Determination of blood glucose concentration}

Blood glucose level was measured by Easy Touch GCU glucose strip in type: ET-301 (Boehringer). The glucose levels were expressed in mg/dl. Blood glucose concentration from a sample taken from the tail vein was measured using the Easy Touch $®$ blood glucose meter (Boehringer).

\section{Antidiabetic testing in an alloxan-induced diabetic model}

Based on the results of the glucose tolerance test dose was chosen for testing in an alloxan-induced diabetic rat model. The rats were divided Into four groups: Group I (normal group); Group II (negative control, receiving 0.5\% CMC-Na); Group III (positive control, receiving $0.45 \mathrm{mg} / \mathrm{kg}$ glibenclamide); Group IV (positive control group, receiving $4.5 \mathrm{mg} / \mathrm{kg}$ ascorbic acid); Groups V, VI and VII, each given $n$-hexane extract, ethyl acetate, and ethanol extract of kabau at $250 \mathrm{mg} / \mathrm{kg}$, respectively. Group of animals before administering the test material/extract (excluding those in the normal group) were treated with $120 \mathrm{mg} / \mathrm{kg}$ alloxan for seven days. The rats that were used as a diabetic model were those with a fasting glucose level of $>126 \mathrm{mg} / \mathrm{dl}$ and showed the signs of polyuria and polydipsia. On day 15 the rats were sacrificed $\mathrm{CO}_{2}$. Immediately afterward, $3 \mathrm{ml}$ of blood was taken from the heart.

\section{In vivo antidiabetic evaluation in high fat feed-induced rats}

Feeding with a high-fat diet formula aims to make experimental animals a model of type 2 diabetes mellitus where insulin resistance occurs. Excess fat in the body causes obesity and causes the pancreatic beta-cell response to glucose to be reduced. In addition, insulin responses to targets throughout the body, including muscle, will be reduced in number and less sensitive so that the presence of insulin in cells becomes underutilized or not utilized [15]

After the rat's body weight increased, then 25 male wistar rats were divided into 5 groups of 5 rats. Each group was given a different treatment. Group I (negative control, given 0.5\% CMC-Na); Group II (positive control, receiving $0.45 \mathrm{mg} / \mathrm{kg}$ metformin); Group III, IV, and $V$ each received $n$-hexane, ethyl acetate, and ethanol extract of kabau at $250 \mathrm{mg} / \mathrm{kg}$, respectively. Upon completing the treatment, all rats were tested for measurement of glucose level, and MDA as well as SOD activities. On the 15th day rats were sacrificed using C02. Immediately afterward, $3 \mathrm{ml}$ of blood was taken from the heart.

Measurement of glucose levels by the enzymatic method of glucose oxidase-phenol aminophenazone (GOD-PAP)

About $10 \mu \mathrm{l}$ serum was mixed with $1000 \mu \mathrm{l}$ glucose liquefaction reagents and incubated for $10 \mathrm{~min}$ at $20^{\circ}-25^{\circ} \mathrm{C}$. The absorbance of the reaction result was measured using a spectrophotometer at a wavelength of $510 \mathrm{~nm}$. The data obtained is then processed using ANOVA analysis [16].

\section{Measurement of MDA (malondialdehyde) activity}

A $200 \mu \mathrm{l}$ serum from each rat was taken and then added with 2000 $\mu \mathrm{l} 20 \%$ trichloroacetic acid (TCA) and $2000 \mu \mathrm{l} 0.067 \%$ thiobarbituric acid (TBA). The homogeneous solution was heated in a water bath for $10 \mathrm{~min}$, and once cooled, centrifuged at $3000 \mathrm{rpm}$ for $10 \mathrm{~min}$. The absorption of the colored solution formed was measured at a wavelength of $532 \mathrm{~nm}$ using UV-Vis Spectrophotometry [17].

\section{Measurement of SOD (superoxyde dismutase) activity.}

The test material was prepared by inserting into a $3 \mathrm{ml}$ cuvette of 2800 $\mu \mathrm{l}$ sodium carbonate buffer, $100 \mu \mathrm{l}$ sample or standard and $100 \mu \mathrm{l}$ epinephrine solution. A non-test solution was prepared by incorporating $2800 \mu \mathrm{l}$ carbonate buffer, $100 \mu \mathrm{l}$ ion-free water and $100 \mu \mathrm{l}$ epinephrine.

The test material is not absorbed immediately after the addition of epinephrine at a wavelength of $480 \mathrm{~nm}$ with a temperature of $30^{\circ} \mathrm{C}$. The measurements are at $1,2,3$, and $4 \mathrm{~min}$ after the addition of epinephrine the $\delta$ absorption value must be $0.025 / \mathrm{min}$, if more than the material is diluted with a buffer [18].

Table 1: Blood glucose level

\begin{tabular}{|c|c|c|c|c|c|c|}
\hline \multirow[t]{2}{*}{ Treatment group } & \multicolumn{6}{|c|}{ Average blood glucose decrease (mg/dl) } \\
\hline & $\mathbf{0}^{\prime}$ & $30^{\prime}$ & $60^{\prime}$ & 90' & $120^{\prime}$ & 150' \\
\hline Normal control & $78 \pm 12.36 \mathrm{deij}$ & $83.67 \pm 12.92$ & $78.67 \pm 0.47$ & $86.67 \pm 4.64$ & $70.33 \pm 9.39$ & $78.67 \pm 9.03$ \\
\hline Negative control & $82.33 \pm 0.94$ & $129 \pm 11.05$ & $104.67 \pm 2.49$ & $106.67 \pm 4.64$ & $88 \pm 16.39$ & $100 \pm 2.83$ \\
\hline Positive control & $94.67 \pm 6.85$ & $109.33 \pm 12.28$ & $94.33 \pm 15.57$ & $82.67 \pm 14.52$ & $90.67 \pm 8.99$ & $68 \pm 13.14$ \\
\hline$n$-hexane $\mathrm{d} 1$ & $105.33 \pm 9.46 \mathrm{a}$ & $125.67 \pm 11.32 \mathrm{aeh}$ & $108 \pm 11.58$ & $107.67 \pm 18.45$ & $113.33 \pm 6.34$ & $98 \pm 4.9$ \\
\hline$n$-hexane d2 & $114 \pm 10.98$ & $161.33 \pm 10.27$ & $125.67 \pm 8.5$ & $126 \pm 8,6$ & $118.33 \pm 11.9$ & $111.33 \pm 17.31$ \\
\hline$n$-hexane d3 & $89.67 \pm 12.50$ & $127.33 \pm 13.22$ & $111 \pm 0$ & $106 \pm 9.9$ & $104.33 \pm 2.62$ & $103.67 \pm 5.19$ \\
\hline Ethyl acetate $\mathrm{d} 1$ & $100 \pm 13.49$ & $127 \pm 9.27$ & $118.67 \pm 14.82$ & $103.33 \pm 7.54$ & $107 \pm 7.79$ & $82.67 \pm 14.61$ \\
\hline Ethyl acetate $\mathrm{d} 2$ & $101 \pm 12.73$ & $161.33 \pm 5.56$ & $119 \pm 5.1$ & $102 \pm 17.15$ & $112 \pm 7.48$ & $103.33 \pm 3.4$ \\
\hline Ethyl acetate $\mathrm{d} 3$ & $107.67 \pm 6.94$ & $126 \pm 19.13$ & $106 \pm 12.83$ & $115.67 \pm 8.01$ & $112.33 \pm 11.44$ & $104.67 \pm 9.74$ \\
\hline Ethanol 96\% d1 & $108.67 \pm 16.34$ & $139 \pm 18.18$ & $123.67 \pm 18.84$ & $97.67 \pm 7.85$ & $81.67 \pm 16.78$ & $80.67 \pm 15.41$ \\
\hline Ethanol $96 \% \mathrm{~d} 2$ & $89 \pm 13.49$ & $127 \pm 26.87$ & $99.33 \pm 18.37$ & $123 \pm 12.08$ & $100 \pm 21.92$ & $99.67 \pm 0.94$ \\
\hline Ethanol $96 \% \mathrm{~d} 3$ & $100 \pm 16.06$ & $128 \pm 14.31$ & $119 \pm 5.66$ & $111.33 \pm 13.6$ & $110.33 \pm 7.85$ & $93.33 \pm 9.46$ \\
\hline
\end{tabular}

Information: Difference in significance; $\mathrm{P}<0.05$, a; significantly different from normal control, b; significantly different from the positive control, c; significantly different from the negative control, d; significantly different from $n$-hexane d1, e; significantly different from $n$-hexane d2, f; significantly different from $n$-hexane d3, g; significantly different from ethyl acetate d1, h; significantly different from ethyl acetate d2, i; significantly different from ethyl acetate $\mathrm{d} 3$, j; significantly different from ethanol d1, k; significantly different from ethanol d2, l; significantly different from ethanol d3, d1: dosage $250 \mathrm{mg} / \mathrm{kg} \mathrm{BW}$, d2: dosage $500 \mathrm{mg} / \mathrm{kg} \mathrm{BW}$, d3: dosage $750 \mathrm{mg} / \mathrm{kg} \mathrm{BW}$ 


\section{Fractionation from the selected extract}

Extract can reduce blood sugar levels well so that the extract is fractionated by means of solid-liquid fractionation. Using ethyl acetate eluent, ethyl acetate: methanol (1:1), and methanol.

\section{RESULTS}

Extracts obtained by soxhletation of 1349.32 grams dried crude drugs using the escalating polarity of solvents were: extract weight from n-hexane extract of 10.1 grams and extract yield $0.75 \%$; extract weight of ethyl acetate $11.14 \mathrm{~g}$ and the yield was $0.83 \%$; and extract weight from ethanol $96 \%$ of $143.85 \mathrm{~g}$ and the yield was $10.66 \%$. The results of measuring blood glucose levels in all groups can be seen in table 1 . The percentage decrease in blood glucose levels in the $n$ hexane, ethyl acetate and ethanol extracts is shown in table 2.

As shown in fig. 1, mice receiving alloxan treatment at $120 \mathrm{mg} / \mathrm{kg}$ demonstrated polyuria and polydipsia as indicated by increasing in weight of bedding and water consumption. Treatment with test extract as well as the reference drug glibenclamide improved these parameters. And, interestingly, the group treated with the antioxidant ascorbic acid also showed similar improvement. Bedding weight and water consumption returned to normal level when they were measured after seven days of treatment (day 14 of observation).

Table 2: Table of percentage of decrease in blood glucose levels

\begin{tabular}{|c|c|c|c|c|c|c|c|c|c|c|}
\hline \multirow{2}{*}{$\begin{array}{l}\text { Observation } \\
\text { time }\end{array}$} & \multicolumn{10}{|c|}{ Percentage of decrease in blood glucose levels in each treatment group (\%) } \\
\hline & $\begin{array}{l}\text { Positive } \\
\text { control }\end{array}$ & $\begin{array}{l}\text { n-hexane } \\
\text { d1 }\end{array}$ & $\begin{array}{l}\text { n-hexane } \\
\text { d2 }\end{array}$ & $\begin{array}{l}\text { n-hexane } \\
\text { d3 }\end{array}$ & $\begin{array}{l}\text { Ethyl } \\
\text { acetate d1 }\end{array}$ & $\begin{array}{l}\text { Ethyl } \\
\text { acetate d2 }\end{array}$ & $\begin{array}{l}\text { Ethyl } \\
\text { acetate d3 }\end{array}$ & Ethanold1 & $\begin{array}{l}\text { Ethanol } \\
\text { d2 }\end{array}$ & $\begin{array}{l}\text { Ethanol } \\
\text { d3 }\end{array}$ \\
\hline 30 & 25.24 & 23.24 & 9.29 & 7.93 & 16.34 & -3.14 & 25.04 & 15.27 & 3.76 & 15.57 \\
\hline 60 & 20.27 & 18.37 & 13.01 & 0.52 & 3.2 & 5.66 & 22.09 & 10.35 & 7.57 & 3.62 \\
\hline 90 & 31.34 & 19.3 & 14.02 & 5.4 & 19.1 & 21.47 & 16.76 & 29.86 & -10.66 & 9.82 \\
\hline 120 & 9.12 & -1.64 & 1.67 & -11.92 & -1.42 & -5.34 & 2.2 & 27.58 & -10.65 & -6.16 \\
\hline 150 & 40.36 & 23.06 & 19.26 & 3.1 & 32.38 & 14.86 & 20.1 & 36.78 & 5.61 & 19.95 \\
\hline Total & 126.33 & 82.33 & 57.25 & 5.03 & 69.6 & 33.51 & 86.19 & 119.84 & -4.37 & 42.8 \\
\hline
\end{tabular}

Information: d1: dosage $250 \mathrm{mg} / \mathrm{kg}$ bw, d2: dosage $500 \mathrm{mg} / \mathrm{kg}$ bw, d3: dosage $750 \mathrm{mg} / \mathrm{kg}$ bw

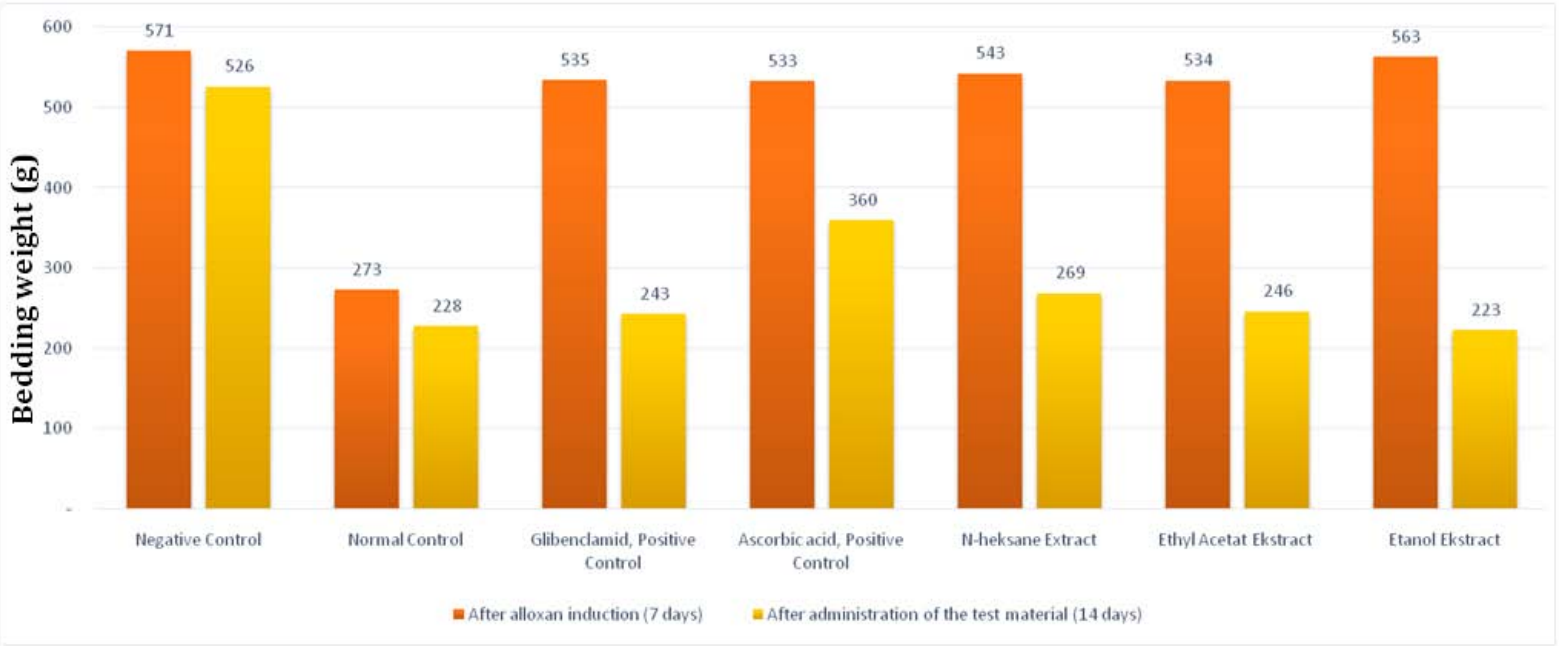

A

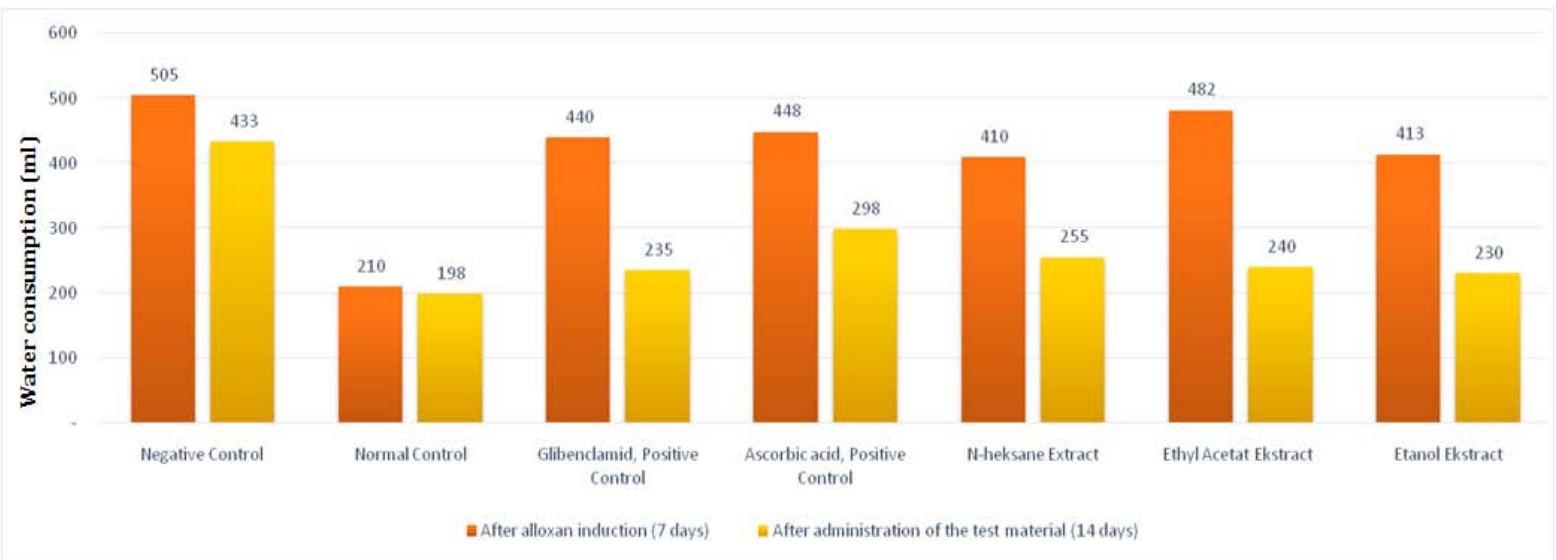

Fig. 1: Effects of kabau extracts on two features of diabetes, polyuria (represented by bedding weight, A) and polydipsia (represented by water consumption, B), in alloxan-induced diabetic mice model. Alloxan was administered at $120 \mathrm{mg} / \mathrm{kg}$, and its effect was tested $7 \mathrm{~d}$ later. Kabau extracts at $250 \mathrm{mg} / \mathrm{kg}$, glibenclamide $(0,45 \mathrm{mg} / \mathrm{kg})$, and ascorbic acid $(4,5 \mathrm{mg} / \mathrm{kg})$ were administered afterwards for $7 \mathrm{~d}$ 
Table 3: Lowering blood sugar levels

\begin{tabular}{lll}
\hline Test group & $\begin{array}{l}\text { Blood sugar levels } 7 \text { d after alloxan induction, } \\
\text { (mg/dl) } \pm \text { SD }\end{array}$ & $\begin{array}{l}\text { Blood sugar levels after 14 d treatment with test } \\
\text { substances, (mg/d) } \pm \text { SD }\end{array}$ \\
\hline Normal control & $109.67 \pm 11.5$ & $126.50 \pm 4.2 \mathrm{bd}$ \\
Negative control & $283.67 \pm 15.01$ & $253.00 \pm 12.6 \mathrm{acd}$ \\
Positive control (glibenclamide) & $258.67 \pm 15.14$ & $118.77 \pm 9.5 \mathrm{bd}$ \\
Positive control (ascorbic acid) & $261.67 \pm 13.6$ & $238.67 \pm 4.9 \mathrm{abc}$ \\
$n$-hexane extract & $289.00 \pm 4.58$ & $227.29 \pm 5.1 \mathrm{abc}$ \\
Ethyl acetate, extract & $260.67 \pm 7.73$ & $223.74 \pm 6.5 \mathrm{abcd}$ \\
Ethanol 96\% extract & $285.00 \pm 9.64$ & $202.94 \pm 2.9 \mathrm{abcd}$ \\
\hline
\end{tabular}

Difference in significance; $\mathrm{P}<0.05$, a: significantly different from the normal group, b: significantly different to the negative group. c: significantly different against the glibenclamide positive group, d: significantly different for the vitamin c positive group

According to [19], MDA is an enzymatic and non-enzymatic product of the breakdown of prostaglandin endoperoxide and the final product of lipid peroxidation. MDA measurements are mostly done to see oxidative damage caused by lipid peroxidation. The principle of this test is the reaction of 1 molecule of MDA with 2 molecules of Thiobarbituric Acid (TBA) forming a complex of pink MDA-TBA compound and its quantity can be read by UV-Vis spectrophotometry at a wavelength of $532 \mathrm{~nm}$ [20]. The results of MDA measurements on the standard curve obtained linear regression $y=0.0044 x+0.1936$. Measurement results can be seen in table 4 .

Table 4: Average MDA levels

\begin{tabular}{ll}
\hline Test group & Average $(\boldsymbol{\mu l} / \mathbf{m l})$ \\
\hline Normal control & $0.194 \pm 0^{\mathrm{bc}}$ \\
Negative control & $0.197 \pm 0^{\mathrm{ac}}$ \\
Positive control (glibenclamide) & $0.194 \pm 0^{\mathrm{bc}}$ \\
Positive control (ascorbic acid) & $0.195 \pm 0^{\mathrm{abc}}$ \\
$n$-hexane extract & $0.196 \pm 0^{\mathrm{abc}}$ \\
Ethyl acetate extract & $0.195 \pm 0^{\mathrm{abc}}$ \\
Ethanol 96\% extract & $0.194 \pm 0^{\mathrm{abc}}$ \\
\hline
\end{tabular}

Information: $\mathrm{a}=$ significantly different from normal control $(\mathrm{p}<0.05), \mathrm{b}=$ significantly different from negative control $(\mathrm{p}<0.05), c$ $=$ significantly different with positive control $(\mathrm{p}<0.05), \mathrm{d}=$ significantly different from the positive control of vitamin $\mathrm{c}(\mathrm{p}<0.05)$
The results of SOD measurement are presented in table 5 . The data showed that while negative control showed reduced activity of SOD, ethanol extract and ascorbic acid produced SOD increases which were significantly different from normal control. The $n$-hexane and ethyl acetate extracts, as well as glibenclamide, showed a tendency of SOD increase.

Table 5: Average results \% inhibited SOD

\begin{tabular}{ll}
\hline Test group & Average \\
\hline Normal control & $26.685 \pm 9$ bd \\
Negative control & $-3.461 \pm 2$ acd \\
Positive control (glibenclamide) & $27.232 \pm 3$ bc \\
Positive control (ascorbic acid) & $72.860 \pm 1$ abc \\
N-heksan extract & $22.586 \pm 1$ bd \\
Ethyl acetat, extract & $36.612 \pm 11$ bd \\
Ethanol 96\% extract & $54.463 \pm 5$ abcd \\
\hline
\end{tabular}

Information: Difference in significance; $\mathrm{P}<0.05$, a: significantly different from the normal group, b: significantly different to the negative group, c: significantly different against the glibenclamide positive group, d: significantly different for the vitamin c positive group

The development of body weight during high-fat feed treatment for $28 \mathrm{~d}$ is presented in fig. 2 . Increases in body weight were observed in all groups.

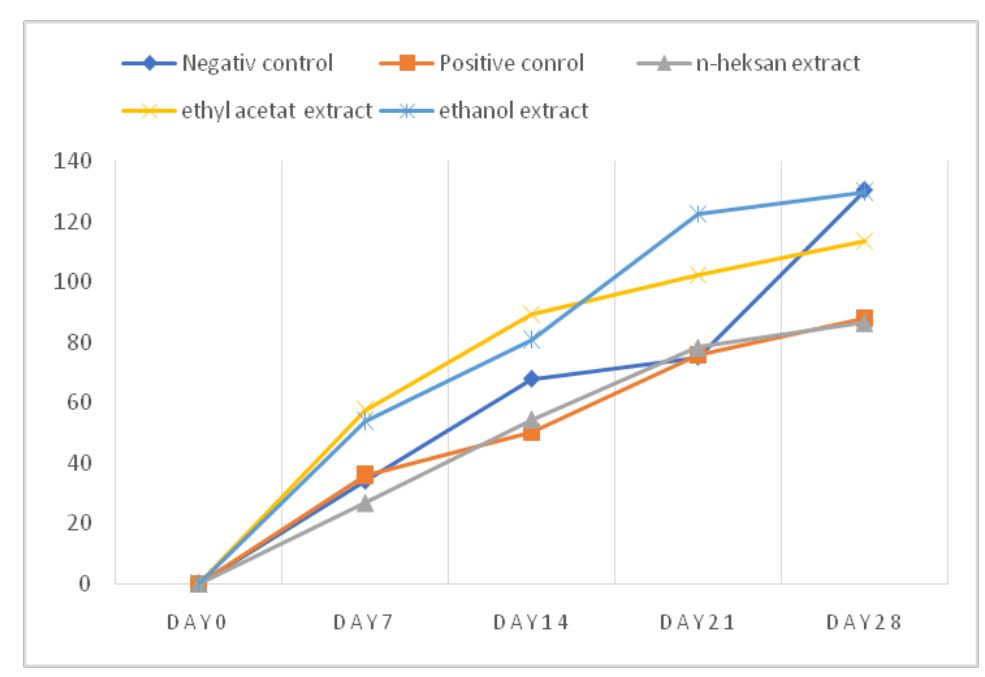

Fig. 2: Development of body weight during administration of high-fat feed

Results of blood glucose measurements are shown in table 6. The data indicated that all mice treated with extracts had lower levels of glucose and ethanol extract produced the highest effect, which was similar to that of the reference drug.
Table 7 shows results of MDA activity measurement in mice treated with high-fat feed. There was no significant difference observed among the groups. However, the tendency of increase in MDA level was observed in groups treated with ethanol extract. 
Table 6: Effects of kabau extracts on blood glucose level in mice fed with high-fat feed

\begin{tabular}{ll}
\hline Test group & Average $(\boldsymbol{\mu l} / \mathrm{ml})$ \\
\hline Negative control & $232,49 \pm 13,93^{\mathrm{b}}$ \\
Positive control & $126,92 \pm 2,94^{\mathrm{a}}$ \\
N-heksan, extract group & $170,48 \pm 46,21^{\mathrm{ab}}$ \\
Ethyl Acetat, extract group & $157,14 \pm 30,01^{\mathrm{ab}}$ \\
Ethanol extract group & $125,33 \pm 22,81^{\mathrm{ab}}$ \\
\hline
\end{tabular}

Information: $\mathrm{a}=$ significantly different from negative control $(\mathrm{p}<0.05), \mathrm{b}=$ significantly different from positive control $(\mathrm{p}<0.05)$

Table 7: Effects of kabau extracts on MDA activity in mice fed with high-fat feed

\begin{tabular}{ll}
\hline Test group & Average activity (Unit/ml) \\
\hline Negative Control & $0,194 \pm 0,7$ \\
Positive Control & $0,194 \pm 0,7$ \\
$n$-hexane, Extract group & $0,194 \pm 0,7$ \\
Ethyl Acetate, Extract group & $0,194 \pm 0,7$ \\
Ethanol Extract Group & $0,194 \pm 1^{\text {ab }}$ \\
\hline
\end{tabular}

Information: $\mathrm{a}=$ significantly different from negative control $(p<0.05), b=$ significantly different from positive control $(p<0.05)$

Effects of kabau extracts on SOD activity in mice treated with highfat feed is shown in table 8. Ethanol extract of Kabau produced an increase in SOD activity to the level of positive control, which received reference drug ascorbic acid.

Table 8: Effects of kabau extracts on SOD activity in mice fed with high-fat feed

\begin{tabular}{ll}
\hline Test group & Average (Unit/ml) \\
\hline Negative Control & $48,30 \pm 59,96^{\mathrm{a}}$ \\
Positive Control & $80,21 \pm 5,6^{\mathrm{b}}$ \\
$n$-hexane, Extract group & $46,71 \pm 70,34^{\mathrm{ab}}$ \\
Ethyl Acetate, Extract group & $33,93 \pm 60,71^{\mathrm{ab}}$ \\
Ethanol Extract Group & $52,55 \pm 117,62^{\mathrm{ab}}$ \\
\hline
\end{tabular}

Information: $a=$ significantly different from negative control $(p<0.05), b=$ significantly different from positive control $(p<0.05)$

Ethanol extract at a dose of $250 \mathrm{mg} / \mathrm{kg} \mathrm{BW}$ can reduce blood sugar levels well so that the ethanol extract is fractionated by means of solid-liquid fractionation. The three fractions were tested for activity screening using the glucose test tolerance (GTT). The following table AUC $_{0-150}$ of the three fractions compared with $96 \%$ ethanol extract.

Table 9: AUC $0-150$ measurement results

\begin{tabular}{ll}
\hline Treatment group & AUC $\left._{\mathbf{0}-\mathbf{1 5 0}} \mathbf{( m g} / \mathbf{d l}\right)$ \\
\hline Normal Group & $16651.705 \pm 430.06^{\mathrm{bc}}$ \\
Negative Group & $56833.48 \pm 4367.96^{\text {cdefgh }}$ \\
Positive Group & $30238.48 \pm 6831.30^{\mathrm{abdefg}}$ \\
Ethanol 96\% Extract & $32695.31 \pm 4576.77^{\mathrm{abefg}}$ \\
Methanol Fraction & $33167.71 \pm 3621.06^{\mathrm{abdfg}}$ \\
Ethyl acetate Fraction & $34631.25 \pm 7618.48^{\mathrm{abg}}$ \\
Ethyl acetate: methanol Fraction & $37409.83 \pm 6543.95 \mathrm{ab}$ \\
\hline
\end{tabular}

Information: a: Significantly different from normal control $(p<0.05)$, $b$ : Significantly different from negative control $(p<0.05)$, c: Significantly different from positive control $(\mathrm{p}<0.05)$, d: Significantly different from $96 \%$ ethanol extract $(\mathrm{p}<0.05)$, e: Significantly different with $100 \%$ methanol fraction $(p<0.05)$, f: Significantly different from the ethyl acetate fraction $(p<0.05)$, g. Significantly different from the ethyl acetate fraction: methanol $(\mathrm{p}<0.05)$

\section{DISCUSSION}

The purpose of extraction is to extract all the chemical components contained in the simplicia. The advantage of this method is that for samples with a soft texture and cannot withstand direct heating, less solvent is used and the heating can be adjusted. The working principle of the Sokhlet tool is continuous filtration where the filter liquid is heated so that it evaporates, the liquid-vapor will be condensed by the solvent liquid molecules by the reverse cooler by descending into the cloning to search for simplicia and then reentering the round bottom flask after passing through the pipe, this process continues until the extraction process is carried out. Active substance to be perfect. In this extraction using solvents in stages, namely n-hexane, ethyl acetate and $96 \%$ ethanol. The type of solvent used affects the active compounds that are also extracted. Polar solvents will attract polar compounds, while non-polar solvents will attract non-polar compounds and semi-polar solvents will attract semi-polar compounds so that the yield of activity testing produced is more selective and effective.

Based on the table of results, the average decrease in blood glucose levels obtained from one way ANOVA analysis data processing, if normal control compared to the negative control, then giving a glucose load of $2 \mathrm{~g} / \mathrm{kg}$ bw did not have a significant effect on increasing blood glucose levels in test animals. Giving positive control showed a significant effect on decreasing blood glucose levels of the test animals at the 150th time after administration of the drug/hypoglycemic effect, glibenclamide showed onset at 150 min. The test materials that showed a significant hypoglycemic effect were ethyl acetate extract at a dose of $250 \mathrm{mg} / \mathrm{kgbw}$ and ethanol at a dose of $250 \mathrm{mg} / \mathrm{kgbw}$, the effect was observed at 150 min after administration of the test material, and there was no significant difference in the potential hypoglycemic effect of the two ingredients. Test at that dose. There was no significant difference in the decrease in blood glucose levels with increasing doses of the test material extracted by each solvent, except for the test material extracted using ethanol. However, the effect was independent of dose. There was no significant difference in decreasing blood glucose levels between the test materials extracted using n-hexane and ethanol. Unless the test material is given at a dose of $250 \mathrm{mg} / \mathrm{kg}$ body weight.

Blood glucose-decreasing activity shown by n-hexane, ethyl acetate and ethanol extracts could be attributable to the flavonoid, phenol and alkaloid content. Flavonoid and phenols have been demonstrated to scavenge free radicals, a contributing factor to the damage to pancreatic beta cells that produce insulin [21,22]. One of the activity of alkaloid has been suggested to be the Inhibition of glucose absorption in the intestine, increasing glucose transport in the blood, stimulating glucogen synthesis and inhibiting glucose synthesis by inhibiting the enzyme glucose 6 -phosphatase, fructose 1,6-bisphosphatase, and increasing glucose 6-phosphate dehydrogenase [23]. The results further showed that the bloodglucose-lowering effect was not dose-dependent, as shown by the lower effect after the $750 \mathrm{mg} / \mathrm{kg}$ extract. This phenomenon has been suggested to relate to relatively lesser content of active substance compared to other substances which might have opposites the activity.

Results of blood glucose measurements were shown in table 3 . Seven days following single alloxan treatment mice in all groups had significantly higher levels of blood glucose compared to those without alloxan treatment (normal control). Upon completion of 14 $\mathrm{d}$ treatment with test extracts or reference drugs, the data showed that mice in ethanol extract-treated group had the largest decrease, from $285.00 \pm 9 \mathrm{mg} / \mathrm{dl}$ to $202.94 \pm 2 \mathrm{mg} / \mathrm{dl}$, which was almost similar to the decrease observed in glibenclamide-treated group. Other groups, including that treated with ascorbic acid showed significant decrease. The data showed that the test groups had lower MDA levels compared to the negative group that was not given extracts. Indicating that kabau seed extracts decreased free radicals which correlated with lower blood glucose levels, among the extracts tested, ethanol extract produced the lowest MDA level, indicating its potential. As an alternative for antidiabetic treatment and as an antioxidant. SOD is an enzymatic antioxidant in the body. SOD is influenced by the degree of oxidative activity. The high activity of SOD will be illustrated by the low lipid oxidation products [24] Reactive oxygen species (ROS) in the body causing the amount of free radicals is far more than antioxidants. Radical compounds can 
react with membrane lipids, nucleic acids, proteins and enzymes that cause cell damage and are often called oxidative stress [25]. Hyperglycemia produces a lot of ROS and this condition will cause pancreatic beta-cell dysfunction. According to [26] that the disrupted function of pad cells will experience decreased levels of antioxidant enzymes such as SOD (superoxide dismutase), glutathione peroxidase $(\mathrm{GPx})$ and catalase (CAT) so that they are prone to oxidative stress.

Based on fig. 2 it is known that feeding for $28 \mathrm{~d}$ increased body weight in all groups. The feed given to increase the bodyweight of experimental animals is a high-fat diet food that contains a lot of carbohydrates. Increased carbohydrate intake can lead to weight gain in test animals; therefore the more carbohydrate intake given to test animals, the more weight the test animals gain. After the rat's body weight increased, then 25 male wistar rats were divided into 5 groups each consisting of 5 individuals; each group was given a different treatment, for the negative control group was given $0.5 \%$ $\mathrm{Na}-\mathrm{CMC}$ and given a drink ad libitum water. In enzymatic testing three methods are performed, namely GOD-PAP, MDA, and SOD. The correlation of the three methods is the GOD-PAP method used to determine the concentration of decreased blood glucose levels after administration of kabau seed extract, while MDA and SOD were performed to determine the percentage of inhibition of blood glucose levels after administration of kabau seed extract. SOD is a natural antioxidant found in the body, an antioxidant function against diabetes that is antioxidants needed to neutralize free radicals so that they can prevent degenerative diseases, one of which is diabetes mellitus. Increasing the supply of sufficient antioxidants will help prevent the clinical complications of diabetes mellitus.

Based on table 9 the administration of the test material showed antihyperglycemic activity in hyperglycemia-induced animals. All test materials showed the same potential antihyperglycemic activity assessed from the value AUC 0-150, which are not significantly different from each other, but when viewed from the decrease in AUC 0.150 , the methanol fraction has the potential to lower glucose levels better than the other fractions.

\section{CONCLUSION}

Plants originating from Indonesia, kabau, which grows endemic in Sumatra, is a large source of potential bioactive components for diabetes therapy and management. The antidiabetic activity of the extract showed that the ethanol extract at a dose of $250 \mathrm{mg} / \mathrm{Kg} \mathrm{BW}$ was better with the glucose test tolerance method, with alloxan induction animal models and high-fat feed induction. In the methanol fraction derived from ethanol $96 \%$ extract, it provides a good reduction in blood sugar levels in the screening method with a glucose test tolerance.

\section{ACKNOWLEDGEMENT}

The authors would like to thank the Indonesian College of Pharmacy (STFI Bandung) and the School of Pharmacy, Bandung Institute of Technology for their support in carrying out research in the laboratory.

\section{FUNDING}

Nil

\section{AUTHORS CONTRIBUTIONS}

All the authors contributed equally.

\section{CONFLICT OF INTERESTS}

Declared none

\section{REFERENCES}

1. Syafnir L, Yani K, Ilma M. Uji aktivitas antidiabtes ekstrak etanol kulit jengkol (Archidendron pauciflorum (benth) I.C Nielsen); 2014.p. 65

2. Sari RP, Maulana APP. Uji aktivitas ekstrak etanol biji petai china (Leucaena leucocephala) terhadap penurunan Kadar glukosa darah pada mencit putih jantan yang diinduksi glukosa. Jurnal Banjarmasin. Akademik Farmasi ISFI Banjarmasin. 2018;3(1):37-44.
3. Kurutas EB. The importance of antioxidants which play a role in cellular response against oxidative/nitrosative stress: current state. Nutr J. 2016;15(1):71. doi: 10.1186/s12937-0160186-5, PMID 27456681.

4. Giugliano D, Ceriello A, Paolisso G. Oxidative stress and diabetic vascular complications. Diabetes Care. 1996;19(3):257-67. doi: 10.2337/diacare.19.3.257, PMID 8742574.

5. Galer BS, Gianas A, Jensen MP. Painful diabetic polyneuropathy: epidemiology, pain description, and quality of life. Diabetes Res Clin Pract. 2000;47(2):123-8. doi: 10.1016/s0168-8227(99) 00112-6, PMID 10670912.

6. Komariah D. Keanekaragaman dan pemanfaatan kabau dan kerabat-kerabatnya (Archidendron spp.) di Sumatra. IPB Press; 2016. p. 44.

7. Simpson MG. Plant systematics. CA: Elsevier Academic Press; 2010.

8. Angiosperm Phylogeny Group. An update of the angiosperm phylogeny group classification for the orders and families of flowering plants: APG IV. Bot J Linn Soc. 2016;181(1):1-20. doi: 10.1111/boj.12385.

9. Zhengyi W, Raven PH, Deyuan H. Flora of china illustration: Fabaceae. Beijing: science. Press and St. Louis: Missouri Botanical Garden Press; 2010. p. 10.

10. Dalimartha S. Atlas tumbuhan obat Indonesia Jilid 4. Jakarta: Puspa Swara; 2006. p. IV.

11. Irawan C, FF, HH, Sulistiawaty L, Sukiman M. Volatile compound analysis using GC-MS, phytochemical screening and antioxidant activities of the husk of "Julang-Jaling" (Archidendron bubalinum (Jack) I.C Nielsen) from Lampung, Indonesia. Pharmacogn J. 2017;10(1):92-8. doi: 10.5530/pj.2018.1.17.

12. Riasari H, Fitriansyah SN, Hartati R, Anggadiredja K, Sukrasno SS Comparison of extraction methods, antioxidant activities, total phenol in seeds and seed shells of kabau (Archidendron bubalinum (Jack) IC Nielsen) from lampung and South Sumatra. Pharmacogn J. 2019;11(6):1278-84. doi: 10.5530/pj.2019.11.198.

13. Liyana $\mathrm{N}$, Teng CP. Total antioxidant activity and enzymatic inhibition against alpha-amylase, alpha-glucosidase and pancreatic lipase of irradiated Archidendron bubalinum. Malays J Med Health Sci. 2019;15(SP1):120-8.

14. Eyth E, Basit H, Simth CJ. Glucose tolerance test. treasure island, (FL): StatPearls Publishing LLC; 2020.

15. Karasawa H, Nagata Goto S, Takaishi K, Kumagae Y. A novel model of type 2 diabetes mellitus based on obesity induced by high-fat diet in BDF1 mice. Metabolism. 2009;58(3):296-303. doi: 10.1016/j.metabol.2008.09.028.

16. Yuriska FA. Efek aloksan terhadap Kadar glukosa darah tikus Wistar [Undergraduated thesis]. Medical faculty; 2009.

17. Nurhasanah F. Efek antioksidan dari ekstrak biji petai cina (Leucaena leucophala L.) pada tikus putih. J Ilmu Kefarmasian Indones. 2005;3(1):13-6.

18. Misra HP, Fridovich I. The role of superoxide anion in the autoxidation of epinephrine and a simple assay for superoxide dismutase.J Biol Chem. 1972; May 25;247(10):3170-5. doi: 10.1016/S0021-9258(19)45228-9, PMID 4623845.

19. Ayala A, Munoz MF, Arguelles S. Lipid peroxidation: production, metabolism, and signaling mechanism of malondialdehyde and 4-hydroxy-2-noenal. Hindawi Publising Corporation. Oxid Med Cell Longev. 2014:1-31.

20. Mendes R, Cardoso C, Pestana C. Measurement of malondialdehyde in fish: a comparison study between HPLC methods and the traditional spectrophotometric test. Food Chem. 2009;112(4):1038-45. doi: 10.1016/j.foodchem.2008.06.052.

21. Krishnaiah D, Bono A, Sarbatly R, Anisuzzaman SM. Antioxidant activity and total phenolic content of an isolated Morinda citrifolia L. methanolic extract from poly-ethersulphone (PES) membrane separator. J King Saud Univ Eng Sci. 2015;27(1):637. doi: 10.1016/j.jksues.2013.01.002.

22. Sharififar F, Dehghn Nudeh G, Mirtajaldini M. Major flavonoids with antioxidant activity from Teucrium polium L. Food Chem. 2009;112(4):885-8. doi: 10.1016/j.foodchem.2008.06.064.

23. Moshi MJ, Lutale JJK, Rimoy GH, Abbas ZG, Josiah RM, Swai ABM. The effect of Phyllanthus amarus aqueous extract on blood glucose in non-insulin dependent diabetic patients. Phytother Res. 2001;15(7):577-80. doi: 10.1002/ptr.780. 
24. Granner DK, Mayes PA, Rodwell VW. Harper's biochemistry. 21st ed. Englewood Cliffs, NJ: Prentice-Hall; 1988. p. 138-9.

25. Giacco F, Brownlee M. Oxidative stress and diabetic complications. Circ Res. 2010;107(9):1058-70. doi: 10.1161/ circresaha.110.223545, PMID 21030723.
26. Robertson RP. Chronic oxidative stress as a central mechanism for glucose toxicity in pancreatic islet beta cells in diabetes. J Biol Chem. 2004;279(41):42351-4. doi: 10.1074/ jbc.R400019200, PMID 15258147. 